\title{
Knowledge, Attitude and Socio-cultural Beliefs of Adolescent Girls Towards Menstruation
}

\author{
Kapoor $\mathbf{A}^{1}$, Khari $\mathbf{S}^{2}$
}

${ }^{1} \mathrm{Dr}$ Anju Kapoor, Professor of Pediatrics, FAIMER fellow from GSMC-FRI, Mumbai, Department of Paediatrics, ${ }^{2}$ Ms. Smriti Khari, Final year MBBS. Both from People's College of Medical Sciences and Research Centre, Bhopal, Madhya Pradesh, India.

\section{Address for correspondence:}

Dr. Anju Kapoor, Professor of Pediatrics

HIG, A/9, PCMS Campus, Bhanpur,

Bhopal, Madhya Pradesh, India. 462037

Tel No; +919993958512

E-mail: dranjukapoor@gmail.com

Acknowledgement: We thank the Indian Council of Medical Research (ICMR) who approved this project for STS-2014.

Funding: Grant of rupees (INR) 10,000.00 has been received by Smriti Khari from Indian Council of Medical Research (STS-2014) after completion of the project.

Conflict of Interest: Oral presentation by Smriti Khari has been done on $30^{\text {th }}$ November, 2014 at Annual National conference of Association of Industrial Psychiatry of India at Bhopal, Madhya Pradesh, India.

Permission from IRB: Yes

Ethical dilemmas faced during study: None

\section{How to cite}

Kapoor A, Khari S. Knowledge, Attitude and Socio-cultural Beliefs of Adolescent Girls Towards Menstruation. J Nepal Paediatr Soc 2016;36(1):42-49.

doi: http://dx.doi.org/10.3126/jnps.v36i1.14386

This work is licensed under a Creative Commons Attribution 3.0 License.

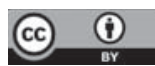

\begin{abstract}
Introduction: Knowledge regarding physiology of menstruation and hygienic practices are poor in adolescent girls. Deep rooted social beliefs make their attitude more negative. Material and Methods: In a hospital based cross sectional study, one hundred adolescent girls who have attained menarche were interviewed with a pre-validated semi-structured questionnaire to assess their knowledge, experiences, effect of mother's education on menstrual hygienic practices and factors affecting their positive and negative attitude. Results: Mean age of menarche was 13.28 (SD \pm 1.42 ) years. Mothers were the first informant to $56 \%$ girls. Only $11 \%$ girls knew that menstruation is a normal biological phenomenon and $28 \%$ girls were mentally prepared before menarche. Readymade pads were being used by $46 \%$ girls. Most girls were forced to follow various restrictions during menstruation. Maternal education was significantly associated with use of readymade pads ( $p$-value 0.031). Significant positive correlation was seen between premenarchal preparedness to pleasantness $(r=0.3215 ; p=0.001)$ while negative correlation was found between preparedness to secrecy $(r=-0.1549$; $p=0.124)$, annoyance $(r=-0.1421 ; p=0.158)$ and worrying thoughts $(r$ $=-0.2074 ; p=0.038$ ). Negative correlation was also seen between years of experience with menses to secrecy and worrying thought $(r=-0.0162 ; p=0.872$ and $r=-0.1033 ; p$ $=0.864$ respectively). Conclusion: There is significant lack of knowledge, poor hygienic practices and negative attitude among adolescent girls that needs to be addressed by educating them and their mothers.
\end{abstract}

Key words: Adolescent girls, menarche, menstruation

\section{Introduction}

A dolescence has been recognized as a special period which denotes the transition from childhood to adulthood. Age group 10-19 years [Early adolescence (10-13 years), Mid adolescence (14-16 years) and Late adolescence (17-19 years)] is considered as the period of adolescence during which sexual development happens along with psychological and cognitive changes. Attaining menarche 
is a very important milestone to mark this developmental process in girls. Normal menstrual cycles are typically 21-35 days long (maximum upto 45 days in early post menarchal year) and last for 3-7 days. Majority of girls are unaware about menarche and menstrual bleeding before they experience it for the first time and are unprepared mentally and emotionally. Attitude towards menstruation, either positive or negative, depends on preparedness of pre-pubescent girls and influenced by socio-cultural environment ${ }^{1}$. It also depends upon awareness, age at menarche, cycle length, intensity and duration of menstrual flow ${ }^{2}$. Girls mostly receive incomplete and inaccurate informations regarding menstruation and their response to menarche depend on degree of physical discomfort they face during menstruation ${ }^{3}$. Lot of myths and taboos regarding sex education prevails among Indian families and menstruation is considered unclean in Indian society. Various restrictions imposed on menstruating girls and secrecy surrounding it affects them psychologically, lowering their self esteem and giving them feeling of shame and disgust. Majority of girls impose self restrictions like going to school or play based on wrong belief that they are physically weak on those days.

Mothers, friends, teachers, relatives media like television are the sources providing information on menstruation. It has been found that girl's knowledge regarding the use of commercially available sanitary pad is positively related to maternal literacy ${ }^{4}$. A key priority for women and girls is to have the necessary knowledge, facilities and the cultural environment to manage menstruation hygienically and with dignity. Many Indian females have some or the other menstrual problems and genital tract infection but they don't consult a health professional due to poor health seeking behavior ${ }^{5}$. Thakre et al in their study concluded that a variety of factors are known to affect menstrual behaviors, the most influential being economic and residential status (urban and rural) ${ }^{6}$.

This was a cross sectional study with an aim to assess the attitude, gaps in the knowledge, beliefs and hygienic practices with respect to menstruation among adolescent girls attending a tertiary care teaching hospital for their various medical problems.

\section{Material and Methods}

This was a hospital based cross-sectional short term project, conducted in a tertiary care hospital, attached to a teaching institute, catering predominantly lower and middle socio economic class. Hundred girls in the age group 10-19 years were included in the study. A convenient sampling method was used for selection of subjects. These girls were subjected to an interview based on semi structured and pre-validated (validated by faculty of Pediatric and OBG Departments) questionnaire in presence of their parents or guardians after taking informed consent.

First part of the questionnaire consisted of demographic data; present age, age at menarche, education, details of their menstrual cycles (duration, length and flow amount) and maternal literacy. Girls were asked for their perception regarding regularity/ irregularity of their cycles. Irregular cycles were taken simply as what is irregular for that individual girl who may fall in the limits of normalcy.

Hygienic practices like what absorbent material they use, how they dispose them off, toilet facility at home and method of cleaning external genitalia were asked. They were questioned for premenstrual symptoms, use of pain killer for dysmenorrhoea and Iron tablet for anemia. Open ended questions were used to assess the knowledge- why girls get periods? Will you worry if you miss your period?

In second part of self administered questionnaire (consisting of 30 items), attitude related questions were asked in three point Likert scale ( 1 being disagree, 2 as neutral and 3 as agree) after translating them in Hindi (Appendix). It included 5 subsets covering areas like preparedness before menarche (8 items; Cronbach alpha 0.76), secrecy (7 items; Cronbach alpha 0.52), pleasantness (6 items; Cronbach alpha 0.56), annoyance (4 items; Cronbach alpha 0.32) and worrying thoughts (5 items; Cronbach alpha 0.44). We have modified the scale originally used by Lisandra Rodriguez White as per local perspective ${ }^{7}$. L R White has utilized 24 items covering three subscales; positive feeling, negative feeling and openness towards menarche from AMAQ(Adolescent Menstrual Attitude Questionnaire) developed by Morse, Kieren \& Botorff, $1993^{\circ}$.

Statistical analysis: Data collection was done over two months period after approval from ICMR (Indian Council of Medical Research) and Institutional Ethics Committee. Data was cleaned, coded and filled into Excel sheet. Percentage, mean and standard deviation were calculated. Chi Square test was applied to study the association. Correlation between premenarchial preparedness to secrecy, worrying thought, annoyance and pleasantness was calculated by Pearson's correlation coefficient. Correlation between years 
of experience with menses to secrecy and worrying thoughts were also calculated. To find out the internal consistency for each subset of questions, Cronbach alpha was calculated by using free online software ${ }^{9}$.

Inclusion criteria: Adolescent girls from 10-19 years of age who have attained menarche and given consent for interview.

Exclusion criteria: Mentally challenged girls of same age group and Girls who themselves or their parents/ guardian refused to give consent

Primary outcome measured: Baseline knowledge, beliefs and practices regarding menstruation among adolescent girls of age group $10-19$ years

Secondary outcomes to be measured were: Effect of maternal literacy on girls' knowledge, beliefs and practices and Effect of premenarchial preparedness on various positive and negative psychological impact like pleasantness, secrecy, worrying thought and annoyance

\section{Results}

Among 100 adolescent girls interviewed, majority belonged to mid adolescence (14-16) years age group $(46 \%)$. All girls were unmarried. Nearly half of the girls' mothers were either illiterate or educated up to $5^{\text {th }}$ standard (Table 1).

In our cohort, mean age of attaining menarche was 13.28 (SD \pm 1.42 ) years. Majority $(75 \%)$ were having irregular cycles but none consulted the doctor for it. Mothers were the first informant regarding menstruation to $56 \%$ girls (table 2 ).

The catchment area of hospital being an urban suburb, $85 \%$ girls had toilet facility at home yet $38 \%$ were using only water without soap or antiseptics for cleaning their external genitalia. Commercially available absorbent pads were exclusively used by $46 \%$ girls only (Table 3).

Crampy lower abdominal pain was the commonest medical complaints amongst all (Table 4).

Various restrictions were imposed on these girls most common being entering into a temple $(70 \%)$ followed by entering into kitchen and touching food items (Table 5).

When asked about the reason why girls get menstruation, large number (42\%) believed that it was for reproduction and only 11 said that it was a normal biological phenomenon (Table 6).
Table 7 shows some positive and negative attitude questions with their responses from Likert scale.

By applying Chi-Squared test, we found that maternal education was significantly associated with girl's practice of using commercially available pad ( $p=$ 0.031 ), although no association was found with use of iron tablets $(p=0.125)$, cleaning practices of external genitalia $(p=0.068)$ and girls' mental preparation for menstruation $(p=0.205)$.

Significant positive correlation was seen between premenarchal preparedness to pleasantness $(r=$ 0.3215; $p=0.001$ ) while negative correlation was found between preparedness to secrecy $(r=-0.1549 ; p=$ $0.124)$, annoyance $(r=-0.1421 ; p=0.158)$ and worrying thoughts $(r=-0.2074 ; p=0.038)$ despite of weak relationships. Negative correlation was seen between years of experience with menses (calculated from current age and age of attaining menarche) to secrecy and worrying thought $(r=-0.0162 ; p=0.872$ and $r=$ $-0.1033 ; p=0.864$ respectively).

Table 1: Demographic characteristics of study patients $(n=100)$

\begin{tabular}{|c|c|c|}
\hline Variables & & $\begin{array}{c}\text { No } \\
(n=100)\end{array}$ \\
\hline \multirow[t]{3}{*}{ Age } & $\begin{array}{l}\text { Early adolescence (11-13 } \\
\text { years) }\end{array}$ & 10 \\
\hline & Mid adolescence (14-16 years) & 46 \\
\hline & $\begin{array}{l}\text { Late adolescence }(17-19 \\
\text { years) }\end{array}$ & 44 \\
\hline \multirow[t]{8}{*}{ Education } & $7^{\text {th }}$ standard & 6 \\
\hline & $8^{\text {th }}$ standard & 13 \\
\hline & $9^{\text {th }}$ standard & 14 \\
\hline & $10^{\text {th }}$ standard & 17 \\
\hline & $11^{\text {th }}$ standard & 9 \\
\hline & $12^{\text {th }}$ standard & 16 \\
\hline & College going & 17 \\
\hline & School dropouts & 8 \\
\hline \multirow[t]{6}{*}{$\begin{array}{l}\text { Maternal } \\
\text { Education }\end{array}$} & Illiterate & 31 \\
\hline & Up to $5^{\text {th }}$ standard & 21 \\
\hline & $6-12^{\text {th }}$ standard & 35 \\
\hline & Graduate & 10 \\
\hline & Post graduate & 2 \\
\hline & Not applicable & 1 \\
\hline \multicolumn{3}{|l|}{ Working } \\
\hline Status Of & Working & 31 \\
\hline \multicolumn{3}{|l|}{ Mother } \\
\hline & Not working & 68 \\
\hline & Not applicable (dead) & 1 \\
\hline
\end{tabular}


Table 2: Details of menstruation of patients included

\begin{tabular}{|c|c|c|}
\hline \multicolumn{2}{|c|}{ Variables } & \multirow{2}{*}{ No $(n=100)$} \\
\hline Menarche & 11 year & \\
\hline & 12 year & 20 \\
\hline \multirow[t]{5}{*}{ (Mean Age - 13.28) } & 13 year & 29 \\
\hline & 14 year & 18 \\
\hline & 15 year & 12 \\
\hline & 16 year & 8 \\
\hline & Don't remember & 2 \\
\hline \multirow[t]{4}{*}{ Menstrual Cycle Length } & Less than 21 days & 4 \\
\hline & $21-35$ days & 90 \\
\hline & More than 35 days & 5 \\
\hline & $\begin{array}{l}\text { Not applicable (attained menarche } 1 \\
\text { month back) }\end{array}$ & 1 \\
\hline \multirow[t]{3}{*}{ Cycle Regularity } & Regular & 24 \\
\hline & Irregular & 75 \\
\hline & $\begin{array}{l}\text { Not applicable (attained menarche } 1 \\
\text { month back) }\end{array}$ & 1 \\
\hline \multirow[t]{3}{*}{ Duration of Menstrual Flow } & Less than 3 days & 10 \\
\hline & $3-7$ days & 84 \\
\hline & More than 7 days & 6 \\
\hline \multirow[t]{7}{*}{ First Informant About Menstruation } & Mother & 56 \\
\hline & Elder sister & 19 \\
\hline & Friends & 11 \\
\hline & School teacher & 11 \\
\hline & Aunt & 1 \\
\hline & Book & 1 \\
\hline & Grand mother & 1 \\
\hline
\end{tabular}

Table 3: Details of maintaining health and hygiene during menstruation

\begin{tabular}{llc}
\hline & Variables & No $(\mathbf{n}=\mathbf{1 0 0})$ \\
\hline Toilet facility at home & Yes & 85 \\
\hline Cleanliness of genitalia & No & 15 \\
\hline & With water only & 38 \\
\hline Absorbent used & Soap and water & 53 \\
\hline & Water, soap and antiseptics & 9 \\
\hline Disposal of absorbent & Commercially available pad & 46 \\
\hline & Homemade cloth & 43 \\
\hline & Both & 11 \\
\hline Taking iron tablets & Wrap in paper/polythene bag and & 75 \\
\hline Taking pain killers & Bispose & 14 \\
\hline & Wash and reuse & 6 \\
\hline & First wash and then burn & 5 \\
\hline
\end{tabular}


Menstruation - Attitude and Beliefs of Adolescent Girls

Table 4: Premenstrual symptoms in study patients

\begin{tabular}{llc}
\hline & Symptoms & Number (n=100) \\
\hline Physical symptoms & Crampy lower abdominal pain & 82 \\
\hline & Pain in lower back and thigh & 44 \\
\hline & Fatigue & 44 \\
\hline & Headache & 10 \\
\hline Emotional and behavioural symptoms & Breast discomfort & 5 \\
\hline & Acne & 3 \\
\hline & Decreased appetite & 1 \\
\hline & Depressed mood & 16 \\
\hline
\end{tabular}

Table 5: Restrictions faced by patients during menstruation

\begin{tabular}{clc}
\hline $\mathbf{S}$ No & Restrictions & Number $(\mathbf{n = 1 0 0})$ \\
\hline 1 & To enter into temple & 70 \\
\hline 2 & To Enter in to kitchen & 43 \\
\hline 3 & To touch food/water/papad/pickle in kitchen & 35 \\
\hline 4 & Avoiding hair wash & 14 \\
\hline 5 & Not allowed to sleep in bed & 10 \\
\hline 6 & Avoid visiting neighbour & 11 \\
\hline 7 & Avoiding long journey & 9 \\
\hline 8 & Complete isolation in home & 7 \\
\hline 9 & Avoid eating sour food & 3 \\
\hline 10 & Avoid attending marriages & 2 \\
\hline 11 & Avoid going out in full moon and new moon & 1 \\
\hline 12 & Avoid touching male members of the family & 1 \\
\hline 13 & Not allowed to go to school & 1 \\
\hline 14 & Avoid applying henna at palm & 1 \\
\hline
\end{tabular}

Table 6: Reasons given by the girls for the cause of menstrual bleeding

\begin{tabular}{clc}
\hline $\mathbf{S}$ No & Reasons & Number $(\mathbf{n = 1 0 0})$ \\
\hline 1 & To purify blood & 39 \\
\hline 2 & To reproduce & 42 \\
\hline 3 & It's a biological phenomenon & 11 \\
\hline 4 & It's a gift of god & 1 \\
\hline 5 & It is important for marriage & 1 \\
\hline 6 & It is a sign of maturity & 1 \\
\hline 7 & It is a sign of virginity & 1 \\
\hline 8 & Do not know & 4 \\
\hline
\end{tabular}


Table 7: Attitude of girls regarding menstruation

\begin{tabular}{clccc}
\hline S No & Attitudes & Agree & Neutral & Disagree \\
\hline 1 & I felt ready before I got my first period due to prior information & 28 & 1 & 71 \\
\hline 2 & I knew how to use pad or cloth before I got my first period & 28 & 0 & 72 \\
\hline 3 & I worry a lot that my period will start unexpectedly & 99 & 0 & 1 \\
\hline 4 & I worry a lot that blood will stain my cloths & 83 & 4 & 13 \\
\hline 5 & I am embarrassed to ask questions about periods & 70 & 8 & 22 \\
\hline 6 & I feel scared that boys will find out that I am having my periods & 43 & 1 & 56 \\
\hline 7 & I am glad that I have become mature enough to menstruate & 28 & 16 & 56 \\
\hline 8 & I felt like a woman once I started menstruating & 77 & 0 & 23 \\
\hline 9 & I felt bad when I came to know that I had started menstruating & 75 & 10 & 15 \\
\hline 10 & I don't like studying regarding menstruation at school & 53 & 16 & 31 \\
\hline
\end{tabular}

\section{Discussion}

In the present study, mean age of menarche was 13.28 (SD 1.42) years, which is in accordance to the study conducted by other authors ${ }^{6,10,11}$. The age of attaining menarche ranged from 11 to 16 years with maximum number between 12-14 years. The difference could be due to hereditary or socio-economic variability.

Majority $(75 \%)$ girls had irregular periods and six had menstrual flow for more than seven days, still none contacted a doctor which showed poor health care seeking behavior in them, an observation supported by other studies also; $5.3 \%$ consulted doctor in study by Singh et al ${ }^{12} ; 7 \%$ in study by A O Busari ${ }^{4}$.

Mother was the first informant regarding menstruation in $56 \%$ cases while in a study conducted among 664 schoolgirls aged 14-18 in Mansoura, Egypt mass media was the main source of information about menstrual hygiene, followed by mothers ${ }^{13}$.

In this study, $71 \%$ girls were found ignorant and psychologically unprepared about menstruation and $72 \%$ did not know how to use sanitary pads before menarche. This was similar to the results reported in a study from Nigeria where $84 \%$ of girls were psychologically unprepared for their first menses ${ }^{14}$. This could be explained by the poor educational status of mothers $(31 \%$ illiterate and $21 \%$ educated up to 5 th standard only) inhibiting them communicating to their daughters regarding sex education.

Present study also showed that only $11 \%$ girls believed it to be a normal physiological process while majority thought that it purifies blood or mean to reproduce where as the other studies reported as 18 to $19 \%{ }^{5,15}$ girls thought it as a normal physiological process.
Khanna et al reported that nearly $70 \%$ girls believed it to be an unnatural process ${ }^{10}$. In contrast, $72.8 \%$ girls in a study conducted by Kamaljit et al believed it to be a normal process ${ }^{16}$.

In the present study, $46 \%$ girls were using commercially available sanitary pads while only $11.25 \%$ girls used sanitary pads in a study conducted by Dasgupta et $\mathrm{al}^{17}$ and approximately $20 \%$ by Khanna et $\mathrm{al}^{10}$. Use of commercially available pad was found to be associated with mother's educational status $(p=0.031)$, similar to the observation by $\mathrm{AO}$ Busari ${ }^{4}$.

In accordance with the study done in Uttrakhand, India ${ }^{15}$ where toilet facility was available to $88 \%$ girls, in present study $85 \%$ girls had toilet facility at home; still many had poor menstrual hygienic practices, thus emphasizing the need of health education to them.

Various restrictions were imposed on menstruating adolescent girls, a social custom also reported by many local and international published literatures. It could be due to socio-cultural beliefs that during menstruation females are in a state of uncleanliness ${ }^{18}$. Although menarche is celebrated hugely in certain societies as a mark of achieving an important developmental milestone in womanhood, menstruation is regarded as something which should be kept secret to avoid embarrassment ${ }^{19}$. These restrictions contribute negatively to their attitude and affect them psychologically that brings low self esteem and feeling of shame and disgust ${ }^{20}$.

Our result was also comparable $(71 \%)$ to the study by Demirbag \& Gungomus, who have also reported that $70.3 \%$ of female students felt inadequately prepared for menarche because of inadequate knowledge of the subject ${ }^{21}$. Unprepared girls having early menarche showed more negative attitude and beliefs related to menstruation 22 . 
The positive association seen between premenarchal preparedness with pleasantness (feeling of grown up and womanhood) and negative association between preparedness to negative attitudes like secrecy, annoyance and worrying thoughts seen in present study are well supported by other published literature ${ }^{19,23}$. Negative attitudes like secrecy and worrying thoughts showed small negative relationship with years of experience after menarche. This finding is supported by Firat et $\mathrm{al}^{24}$.

When asked whether they were comfortable talking to their fathers regarding menses, majority (82\%) said that they are not while a study conducted by Cevirme et al revealed that $48.8 \%$ females hide the fact that they are menstruating from other people especially men ${ }^{25}$.

\section{Conclusion}

Present study concludes that knowledge, beliefs, attitude and practices regarding menstruation among adolescent girls are unsatisfactory in part of central India where it was conducted. Negativity surrounding the menstruation which is a normal physiological process can be reduced by reproductive health education by individuals and society.

\section{References}

1. Roberts T. Female trouble: The menstrual selfevaluation scale and women's self-objectification. Psychol Women Quarterly 2004;28(1):22-26.

2. Morrison LA, Larkspur L, Calibuso MJ, Brown S. Women's attitudes about menstruation and associated health and behavioral characteristics. Am J Health Behavior 2010;34(1):90-100

3. Koff E, Rierdan J. Early adolescent girls' understanding of menstruation. Women Health 1995;22(4):1-19.

4. Busari AO. Menstrual Knowledge and Health Care behavior among Adolescent Girls in Rural, Nigeria. Int J App/ Sci Technol 2012; 2( 4):149-154.

5. Bang RA, Bang AT, Baltule M, Choudhury $\mathrm{Y}$, Sarmikuddam N, Tale $O$. High prevalence of gynaecological disease in rural Indian women. Lancet 1989;1:85-87.

6. Thakre SB, Thakre SS, Reddy M, Rathi N, Pathak K, Ughade S. Menstrual Hygiene: Knowledge and Practice among Adolescent School Girls of Saoner, Nagpur District. J Clin Diag Res 2011;5(5):1027-33.

7. Lisandra Rodriguez White. The Function of Ethnicity, Income Level, and Menstrual Taboos in Postmenarcheal Adolescents' Understanding of Menarche and Menstruation. Sex Roles 2013; 68(1):65-76.

8. Morse J M, Kieren D, Bottorff J. The adolescent menstrual attitude questionnaire, part I: Scale construction. Health Care for Women International 1993;14:39-62.

9. Wessa P, 2014, Cronbach alpha (v1.0.3) in Free Statistics Software (v1.1.23-r7), Office for Research Development and Education, URL http://www.wessa. net/rwasp_cronbach.wasp/

10. Khanna A, Goyal RS, Bhaswar R. Menstrual practices and reproductive problems: a study of adolescent girls in Rajasthan. J Health Manag 2005;7:91-107.
11. Reem Bassiouny El-Lassy and Abeer Abd El-Aziz Madian. Impact of Health Education Program on Menstrual Beliefs and Practices of Adolescent Egyptian Girls at Secondary Technical Nursing School. Life Sci J 2013;10 (2):335-45.

12. Singh MM, Devi R, Gupta SS. Awareness and Health Seeking Behaviours of Rural Adolescent Schools Girls on Menstrual and Reproductive Health problems. Indian J Med Sci 1999:53:439-43.

13. El-Gilany $\mathrm{AH}$, Badawi K. Menstrual hygiene among adolescent schoolgirls in Mansoura, Egypt. Reprod Health Matters 2005;13:147-52.

14. Abioye-Kuteyi EA. Menstrual knowledge and practices amongst secondary school girls in Nigeria. J Soc Health 2000;120:23-26.

15. Raina D, Balodi G. Menstrual hygiene: knowledge, practice and restrictions amongst girls of Dehradun, Uttarakhand, India. GJISS 2014;3(4):156-62.

16. Kamaljit K, Arora B, Singh GK, Neki NS. Social Beliefs and Practices associated with Menstrual Hygiene among Adolescent Girls of Amritsar, Punjab, India. JIMSA 2012;25 (2):69-70.

17. Dasgupta A, M Sarkar. Menstrual Hygiene: How Hygienic is the Adolescent Girl? Indian J Comm Med 2008;33(2):78-80.

18. Buckley T, Gottlieb A. (1988). A critical appraisal of theories of menstrual symbolism. Blood magic: The anthropology of menstruation. USA: University of California Press

19. Marván ML, Molina-Abolnik M. Mexican adolescents' experience of menarche and attitudes toward menstruation: Role of communication between mothers and daughters. J Pediatr Adolesc Gynecol 2012;25(6):358-63.

20. Umeora OUJ, Egwuatu VE. Menstruation in rural Igbo women of South East Nigeria: Attitudes, beliefs and 
practices. African J Reproductive Health / La Revue Africaine De La Santé Reproductive. 2008;12(1):10915.

21. Demirbag $B C$, Güngörmüs $Z$. An investigation into the knowledge about the menstruation period among the female university students at Eastern Black Sea region of Turkey. Health Med 2011;5(6):1643-6.

22. Tiwari H, Oza UN, Tiwari R.. Knowledge, attitudes and beliefs about menarche of adolescent girls in Anand district, Gujarat. Eastern Mediterranean Health $J$ 2006;12(3-4):428-33.

23. Shanbhag D, Shilpa R, D'Souza N, Josephine P, Singh $\mathrm{J}$, Goud BR. Perceptions regarding menstruation and practices during menstrual cycles among high school going adolescent girls in resource limited settings around Bangalore city, Karnataka, India. Int $J$ Collaborative Res Internal Med Pub Health (IJCRIMPH) 2012;4(7):1353-62.

24. Firat MZ, Kulakaç Ö, Öncel S, Akcan A. Menstrual attitude questionnaire: confirmatory and exploratory factor analysis with Turkish samples. J Adv Nurs 2009;65(3):652-62.

25. Çevirme AS, Çevirme H, Karaoglu L, Ugurlu N, Korkmaz $\mathrm{Y}$. The perception of menarche and menstruation among Turkish married women: Attitudes, experiences, and behaviors. Social Behavior \& Personality: An Int J 2010;38(3):381-93.

Please read each sentence and tell me how much you agree or disagree with each one. Please tick only one

\begin{tabular}{|c|c|c|c|c|}
\hline S.No. & जानकारी (Awareness) & D & $N$ & $\Lambda$ \\
\hline 1 & मुझो उपयोगी जानकारी दी गई थी मेरे पहले चक्र से पूर्व & & & \\
\hline 2 & मैं पूरी तरह से तैयार थी पहले चक्र से पूर्व & & & \\
\hline 3 & मैं जानती थी कि मुझे क्या करना है & & & \\
\hline 4 & मैं जानती थी कि मेरे शरीर को क्या हो रहा है & & & \\
\hline 5 & मेरे पास उचित सामग्री उपलव्ध थी & & & \\
\hline 6 & मुझो पता था कि कैसे कपडे का प्रयोग करना है & & & \\
\hline 7 & मेरे चक्र के दौरान मुझो भय था कि लडके इस बारे में जान जाएँगे & & & \\
\hline 8 & मैंने यह बात किसी को नहीं बताई थी कि मेरी महवारी शुरू हो चुकी हैं & & & \\
\hline 9 & मुझे मेरे पिताजी से इस बारे में बात करने में झिइाक होती है & & & \\
\hline 10 & मुझे महवारी के बारे में जानकर खुशी हुई & & & \\
\hline 11 & मुझे हिचकिचाहट होतीं है, दुकान पर पैड खरीदते समय & & . & \\
\hline 12 & यह सच जानके कि मुझे महवारी होती हैं, मुझो बुरा लगा & & & \\
\hline 13 & मेरी पहली महवारी के दौरान मैं डरी हुई थी & & & \\
\hline 14 & मैं नहीं चाहती कि कोई मुझे कचरे में पैड डालते हुए देखे & & & \\
\hline 15 & मुझे मेंरे मित्रों से महवारी के विषय में वात करने में हिचकिचाहट है & & & \\
\hline 16 & मुझे चिंता रहती है कि मेंरे कपड़ों में दाग ना लग जाए & & & \\
\hline 17 & मैं मेरे महावारी के लिए और प्रतीक्षा नहीं करना चाहती थी & & & \\
\hline 18 & मुझे महवारी शुरू होने पर बड़े होने का एहसास हुआ & & & \\
\hline 19 & मैं बहुत ही उत्तेजित थी जब मुझो पहला मासिक धर्म आया & & & \\
\hline 20 & मुझे विद्यालय मे महवारी के बारे में पढ़ना पसंद नहीं & & & \\
\hline 21 & मुझे भय रहता है कि लोगों को पता चल जाएगा मेरी महवारी के वारे मे & & & \\
\hline 22 & यदि कोई महवारी के बारे में बोलता है तो मैं घबरा जाती हूँ & & & \\
\hline 23 & यह जान कर कि मैं बड़ी हो गई हूँ महवारी के लिए मुझे खुशी हुयी & & & \\
\hline 24 & मैं लडकों से मासिक धर्म के बारे में बात करने से संकोच नहीं करती & & & \\
\hline 25 & मुझे गर्व होता है कि मुझे महवारी होती है & & & \\
\hline 26 & महवारी के समय मैं अपने आप को बदसूरत महसूस करती हूँ & & & \\
\hline 27 & दर्द की गोली का इस्तेमाल पूर्ण रूप से सुरक्षित हैं & & & \\
\hline 28 & मैं विद्यालय से छुट्टी लेती हूँ महवारी के समय & & & \\
\hline 29 & जब मेरे महवारी का समय नजदीक होता है तब मैं तनाव में रहती हूँ & & & \\
\hline 30 & मैं आराम से महवारी के समय सो लेती हूँ & & & \\
\hline
\end{tabular}

APPENDIX

$D=$ Disagree,$N=$ Neutral,$A=$ Agree 